Jurnal Algoritme

Vol. 1, No. 1, Oktober 2020, Hal. 57 - 67

\title{
Segmentasi Buah Mangga Menggunakan MLE dan GMM Sebagai Klasterisasi Pixel
}

\author{
Steven Pranata ${ }^{1}$, Derry Alamsyah ${ }^{* 2}$ \\ ${ }^{1,2}$ STMIK GI MDP; Jalan Rajawali 14, Palembang, 0711-376-400 \\ ${ }^{1,2}$ Jurusan Teknik Informatika, STMIK GI MDP Palembang \\ e-mail: ${ }^{1}$ stevenpranata@mhs.mdp.ac.id, ${ }^{2}$ derry@mdp.ac.id
}

\begin{abstract}
Abstrak
Segmentasi membagi suatu citra menjadi bagian-bagian atau segmen yang lebih sederhana dan bermakna sehingga dapat dianalisis lebih lanjut. Penyelesaian yang telah ditemukan adalah menggunakan metode Maximum Likelihood Estimation (MLE) dan Gausian Mixture Model. GMM adalah salah satu metode clustering. GMM adalah fungsi yang terdiri dari beberapa Gaussian, masing-masing diidentifikasi oleh $k \in\{1, \ldots, K\}$, di mana $K$ adalah jumlah cluster dataset kita. Maximum Likelihood estimation adalah teknik yang digunakan untuk mencari titik tertentu untuk memaksimumkan sebuah fungsi, teknik ini sangat luas dipakai dalam penaksiran suatu parameter distribusi data. Pengujian dilakukan dengan menggunakan citra mangga dengan 10 background yang berbeda. GMM akan melakukan clustering pada pixel citra mangga tersebut akan menghasilkan rata-rata dan kovarian. Kemudian rata-rata dan kovarian akan dipakai oleh MLE untuk mengkasifikasi setiap pixel citra mangga. Pada penelitian ini dilakukanlah pengujian GMM dan MLE untuk melakukan segmentasi buah mangga. Berdasarkan hasil yang didapat, metode GMM dan MLE mempunyai tingkat kesalahan sebesar 13,07\% untuk 3 cluster, 8,06\% untuk 4 cluster, dan 6,63\% untuk 5 cluster dan mempunyai kualitas klaster yang baik dengan nilai silhouette coefficient sebesar 0,37686 untuk 3 cluster, 0,29577 untuk 4 cluster, dan 0,26162 untuk 5 cluster.
\end{abstract}

Kata kunci-Segmentasi, Clustering, GMM, MLE, Silhouette

\begin{abstract}
Segmentation divides an image into parts or segments that are simpler and more meaningful so they can be analyzed further. The solution that has been found is using the Maximum Likelihood Estimation (MLE) method and the Gausian Mixture Model. GMM is a clustering method. GMM is a function consisting of several Gaussian, each identified by $k \in\{1, \ldots, K\}$, where $K$ is the number of clusters in our dataset. Maximum Likelihood estimation is a technique used to find a certain point to maximize a function, this technique is very widely used in estimating a data distribution parameter. Tests carried out using mango images with 10 different backgrounds. GMM will cluster the pixels of the mango image to produce averages and covariates. Then the average and covariance will be used by MLE to qualify each pixel of the mango image. In this study GMM and MLE tests were carried out to segment mangoes. Based on the results obtained, the GMM and MLE methods have an error rate of $13.07 \%$ for 3 clusters, $8.06 \%$ for 4 clusters, and $6.63 \%$ for 5 clusters and good cluster quality with silhouette coefficient values of 0.37686 for 3 clusters, 0.29577 for 4 clusters, and 0.26162 for 5 clusters.
\end{abstract}

Keywords - Segmentation, Clustering, GMM, MLE, Silhouette 


\section{PENDAHULUAN}

$\mathrm{B}$ uah adalah unsur makanan yang tidak dapat terpisahkan dari masyarakat Indonesia. Buah yang sering dikonsumsi atau diminati oleh masyarakat Indonesia adalah buah mangga. Kita dapat mengenali buah mangga berdasarkan ciri-ciri bentuknya. Dalam proses pengenalan buah mangga diperlukan suatu pemisahan atau segmen tertentu dalam citra yang akurat, proses pemisahan tersebut dikenal sebagai proses segmentasi (Putranto, dkk, 2010). Segmentasi membagi suatu citra menjadi bagian-bagian atau segmen yang lebih sederhana dan bermakna sehingga dapat dianalisis lebih lanjut.

Metode yang dapat digunakan dalam segmentasi, antara lain yaitu Thresholding untuk menghasilkan citra biner. Segmentasi Citra Digital Ikan Menggunakan Metode Thresholding berhasil memisahkan objek mata ikan dengan nilai T3 $=61$ (Kumaseh, dkk, 2013). Fuzzy CMeans, Konsep dasar Fuzzy C-means adalah menentukan pusat kluster. Dengan cara memperbaiki pusat kluster dan nilai keanggotaan dari tiap-tiap data secara berulang, maka dapat dilihat bahwa pusat kluster akan menuju lokasi yang tepat (Amaluddin, dkk, 2015). Hasil dari metode Fuzzy C-Means memilikit tingkat akurasi sebesar 91,3\%.

Selain itu segmentasi Maximum Likelihood Estimation (MLE) merupakan salah satu metode Supervised Learning. Maximum Likelihood Estimation adalah metode yang menentukan nilai untuk parameter suatu model. Nilai parameter ditemukan sedemikian rupa sehingga mereka memaksimalkan kemungkinan proses yang digambarkan oleh model menghasilkan data yang benar-benar diamati. Penggunaan MLE pada Regularized Weighted Collaborative Representation with Maximum Likelihood Estimation for Facial Expression Recognition menunjukkan bahwa Hasil percobaan pada basis data CohnKanade menunjukkan bahwa metode yang diusulkan efektif dalam segmentasi dan dapat mencapai hasil akurasi yang memuaskan(Dang,dkk, 2017). Penggunaan MLE dalam A Maximum Likelihood Classification Method For Image Segmentation Considering Subject Variability menunjukkan model yang diusulkan dapat meningkatkan hasil segmentasi (Liu, 2010).

Selanjutnya Gaussian Mixture Model (GMM) merupakan salah satu metode clustering untuk melakukan segmentasi. Dalam model, objek data dianggap berasal dari berbagai komponen, dan masing-masing sumber dimodelkan oleh distribusi Gaussian. Gaussian Mixture model adalah salah satu model yang baik dan banyak digunakan untuk clustering. Penggunaan GMM dalam Object Segmentation Based on Gaussian Mixture Model and Conditional Random Fields menunjukkan bahwa GMM kompetitif untuk model segmentasi objek(Zhang, Li, 2016). Penggunaan GMM pada Foreground Detection of Moving Object Using Gaussian Mixture Model menunjukkan bahwa GMM mendeteksi objek bergerak secara efektif ketika terhalang oleh kotak (Aslam, Sharma, 2017). Penggunaan GMM pada Segmentasi Kendaraan Menggunakan Gaussian Mixture Model (GMM) dan Fuzzy Cluster Means (FCM) memiliki nilai akurasi sebesar 91,3\%. Penggunaan GMM pada Online Video Foreground Segmentation Using General Gaussian Mixture Modeling menunjukkan hasil yang memuaskan dalam memisahkan pixel foreground dan background (Alili, dkk, 2007).

Berdasarkan uraian paragraf sebelumnya, penelitian ini akan menggunakan tahapan yaitu, tahapan ektraksi fitur, tahap segmentasi, dan tahap segmentasi dengan metode yang berbeda. Tahap ektraksi fitur menggunakan raw pixel, tahap clustering menggunakan Gaussian Mixture Model (GMM), dan tahap segmentasi Supervised Learning dengan metode Maximum Likelihood Estimation (MLE). Penelitian segmentasi buah mangga menggunakan GMM dan MLE belum pernah dilakukan, oleh karena itu penelitian ini penting dilakukan untuk mengetahui tingkat akurasinya. Maka dilakukan penelitian dalam menerapkan metode GMM dan MLE dalam melakukan segmentasi buah mangga.

Pranata, et., al (Segmentasi Buah Mangga Menggunakan MLE dan GMM Sebagai Klasterisasi Pixel) 


\section{METODE PENELITIAN}

1. Identifikasi Masalah

Pada tahapan ini yaitu menemukan permasalahan sesuai bidang ilmu, dalam hal ini adalah segmentasi buah mangga.

2. Studi Literatur

Pada tahapan ini, dilakukan pencarian beberapa jurnal, buku, dan hasil penelitian yang berkaitan dengan segmentasi buah mangga menggunakan berbagai macam metode, jurnal yang terkait mengenai Gaussian Mixture Model dan metode terkait yaitu metode Maximum Likelihood Estimation

3. Pengumpulan Data

Pengumpulan data menggunakan dataset yang berjumlah 100 gambar yang terdiri dari 10 background yang berbeda yang setiap backgroundnya terdapat 10 citra mangga. Data tersebut diambil sendiri menggunakan kamera yang memiliki resolusi 8 megapixel. Contoh Dataset yang digunakan dapat dilihat seperti pada gambar 1 .

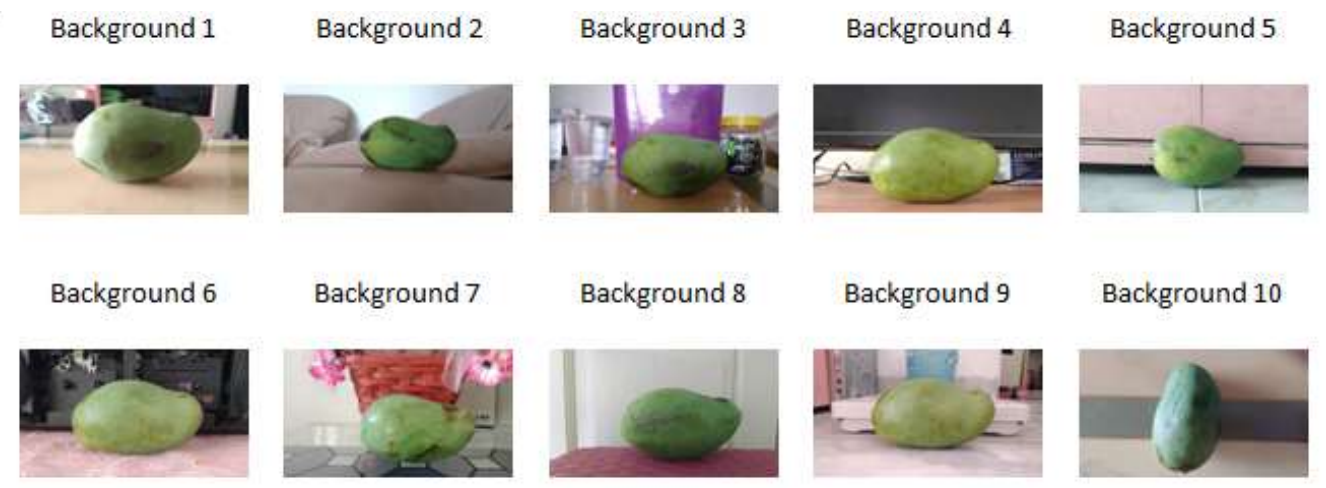

Gambar 1 Dataset Mangga

4. Perancangan Sistem

Perancangan dilakukan dengan mengumpulkan dataset buah mangga. Kemudian melakukan tahapan ekstraksi ciri menggunakan raw pixel, dilanjutkan dengan tahap clustering menggunakan Gaussian Mixture Model, dan disegmentasi menggunakan metode Maximum Likelihood Estimation (MLE) dengan tahap perancangan seperti pada Gambar 3.3.

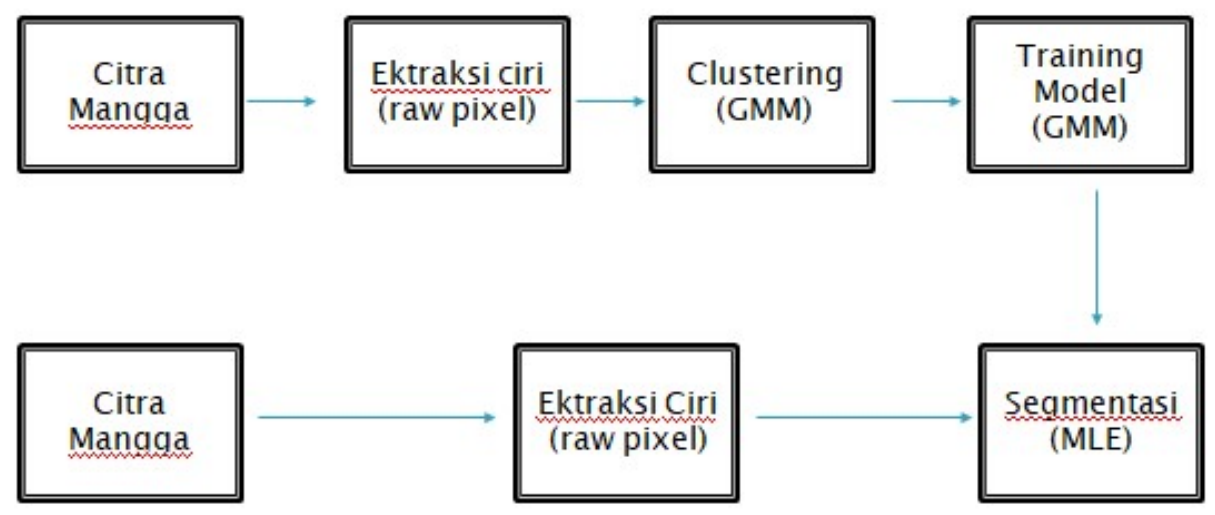

Gambar 2 Perancangan Sistem

Pranata, et., al (Segmentasi Buah Mangga Menggunakan MLE dan GMM Sebagai Klasterisasi 
5. Implementasi

Setelah melakukan analisis dan desain, tahap selanjutnya adalah melakukan implementasi terhadap rancangan yang telah dibuat ke bentuk program dalam bahasa pemrograman.

6. Evaluasi

Evaluasi program dilakukan untuk memastikan semua bagian berjalan sesuai dengan tujuan. Tujuan tahap ini adalah untuk mengukur tingkat kesalahan dan kualitas klaster serta memastikan keluaran yang dihasilkan sesuai keinginan. Hasil pengujian akan didokumentasikan dalam bentuk tabel dengan parameter Mean Absolute Error (MAE) dan Shilhouette Coefficient. Cara perhitungan Nilai error dan Silhouette Coefficient tersebut dapat dilihat pada persamaan (3.1) dan (3.2). Citra Mangga yang telah dilabel (Ground Truth) akan dibandingkan dengan hasil klaster mangga untuk mencari nilai selisih atau tingkat kesalahan dari mangga tersebut.

$$
M A E=\frac{1}{n} \sum_{i=1}^{n}|f i-y i|(1)
$$

Dimana $f($ i) adalah nilai hasil peramalan, $y(i)$ adalah nilai sebenarnya, dan $n$ adalah jumlah data.

$$
s(i)=\frac{b(i)-a(i)}{\max \{a(i), b(i)\}}(2)
$$

Dimana $a($ i) sebagai rata-rata jarak antara objek $i$ dengan semua objek lain dalam klaster tersebut dan $b($ i) sebagai rata-rata jarak minimum dari objek $i$ ke semua klaster lain. Jika nilai Silhouette Coefficient dari 0 mendekati 1, berarti klaster yang berisi objek $i$ sangat padat dan objek $i$ terpisah jauh dari klaster-klaster lain. Sebaliknya, jika nilai Silhouette Coefficient dari 0 mendekati -1 , berarti klaster yang berisi objek $i$ tidak padat dan objek $i$ sangat dekat dengan klaster-klaster lain.

\section{HASIL DAN PEMBAHASAN}

\subsection{Implementasi}

Tahap ini mengimplementasikan proses pada penelitian untuk mendapatkan hasil yang dibutuhkan pada penelitian ini, seperti klasterisasi GMM dan MLE untuk proses segmentasinya.

\subsubsection{Implementasi GMM}

Pada tahap ini, citra mangga akan di klaster menggunakan GMM. Kemudian hasil klaster GMM akan mendapatkan nilai rata-rata $(\sigma)$ dan kovarian $(\Sigma)$ untuk melakukan proses segmentasi MLE untuk setiap pixel, disini penulis memberikan contoh dengan menggunakan salah satu citra mangga. Setelah mendapatkan nilai rata-rata dan kovarian, akan digunakan oleh MLE untuk mengsegmentasi setiap pixel pada citra tersebut. Hasil GMM dapat dilihat pada Gambar 3

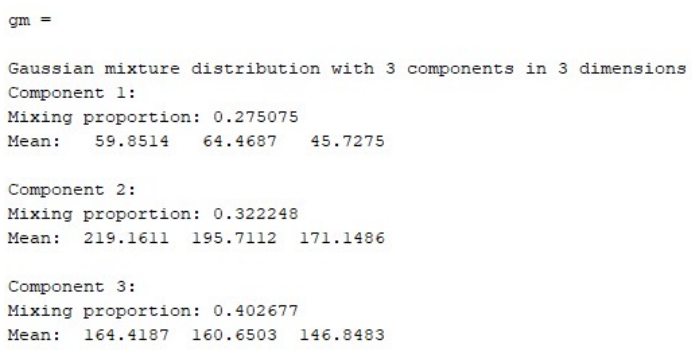

Gambar 3 Klasterisasi GMM 


\subsubsection{Implementasi MLE}

Pada tahap segmentasi MLE, citra mangga akan melakukan segmentasi dengan nilai rata-rata $(\sigma)$ dan kovarian $(\Sigma)$ yang telah didapatkan dari GMM menggunakan fungsi Multivariate Normal Distribution untuk setiap pixel pada citra mangga. Contoh Hasil segmentasi MLE dapat dilihat pada Gambar 4.2
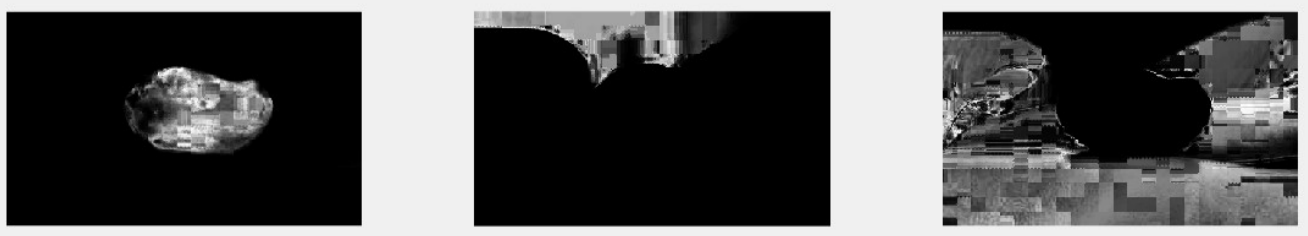

Gambar Error! No text of specified style in document. Hasil Segmentasi MLE

\subsection{Pengujian dan Hasil}

Pada tahap pengujian dilakukan pada 10 background berbeda, setiap background terdapat 10 gambar dan total seluruh mangga adalah seratus (100) gambar serta pengujian dilakukan dengan jumlah cluster yang berbeda, yaitu 3 cluster, 4 cluster, dan 5 cluster. Pada tahap penentuan hasil pengujian, dilakukan perhitungan dengan mencari selisih antara mangga yang telah dilabel (Ground Truth) dengan mangga hasil segmentasi untuk mendapatkan tingkat error menggunakan MAE dan nilai Silhoutte Coefficient untuk mengukur kepadataan klaster dan jarak antar klaster. Contoh Citra yang telah dilabel (Ground Truth) dapat dilihat pada Gambar 4.3.

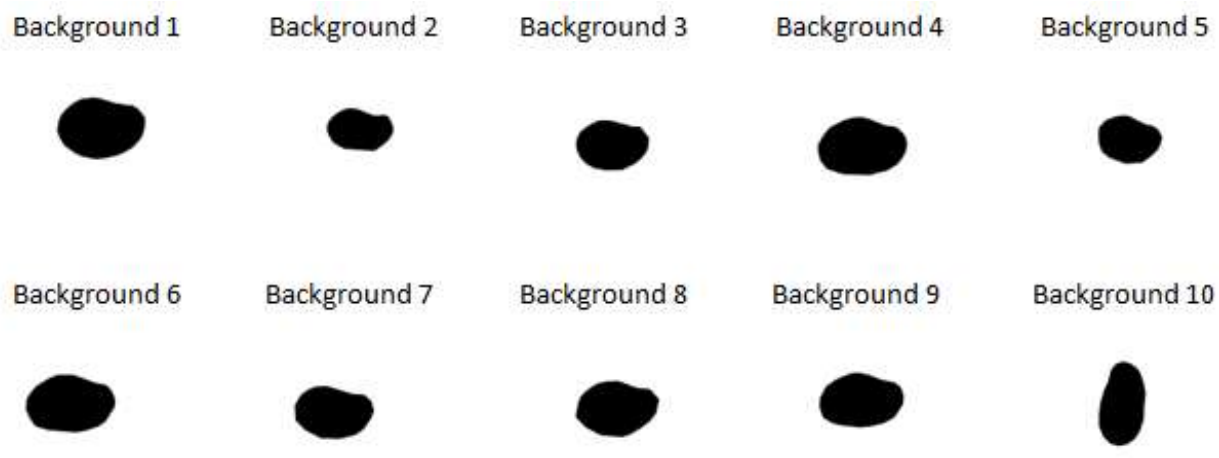

Gambar 5 Citra yang telah dilabel

Berikut hasil yang didapat pada pengujian yang telah didapat menggunakan MAE dan Silhoutte Coefficient yang ditampilkan dalam bentuk berupa tabel yang dapat dilihat pada Tabel berikut. 


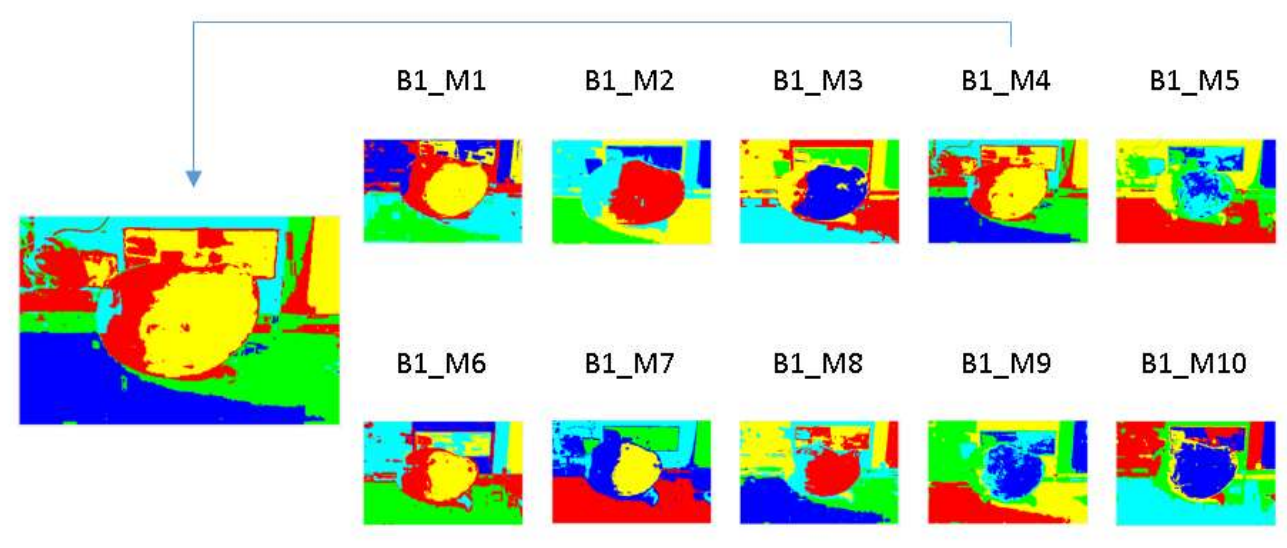

Gambar 1 Hasil Segmentasi 5 klaster pada background 1

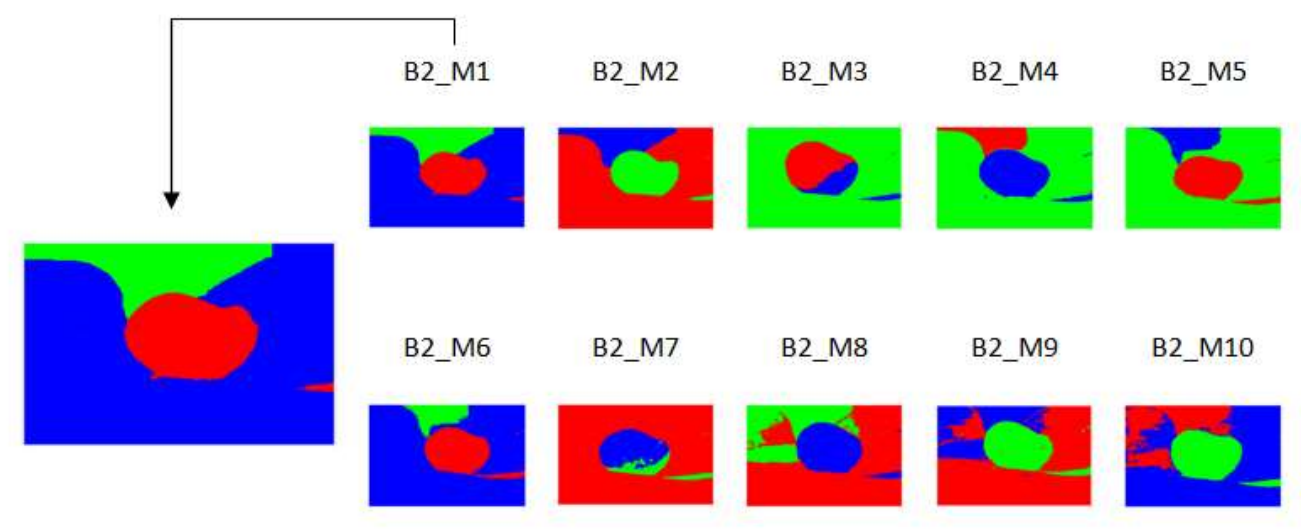

Gambar 7 Hasil Segmentasi 3 klaster pada background 2

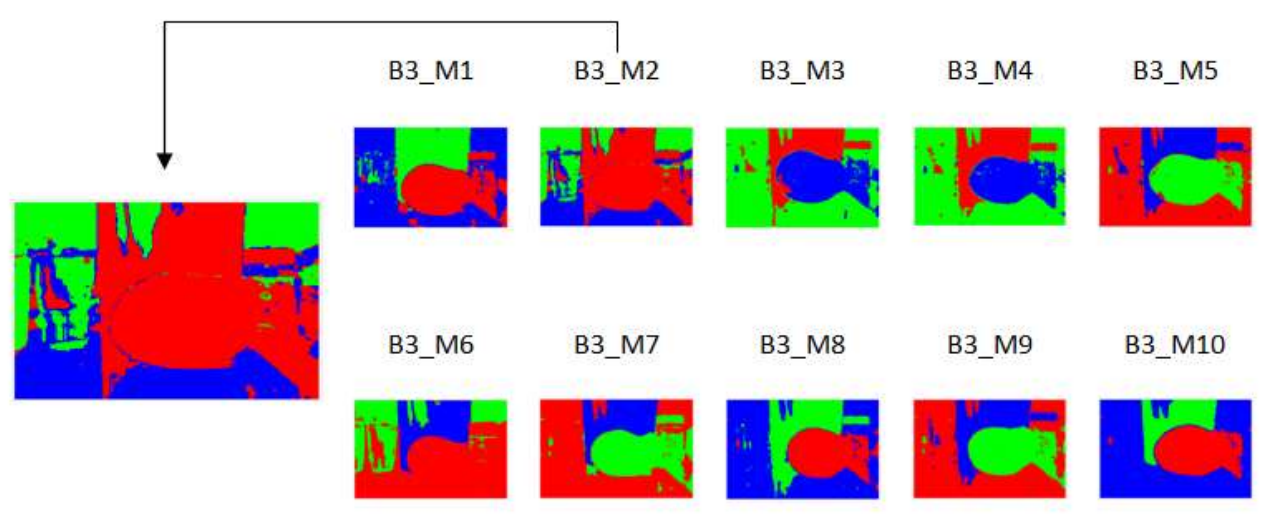

Gambar 8 Hasil Segmentasi 3 klaster pada background 3

Pranata, et., al (Segmentasi Buah Mangga Menggunakan MLE dan GMM Sebagai Klasterisasi Pixel) 


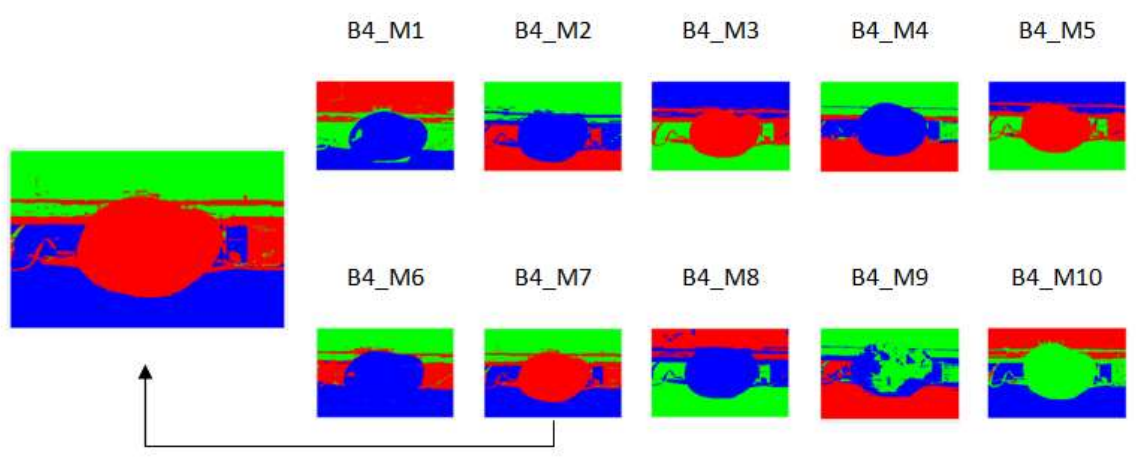

Gambar 9 Hasil Segmentasi 3 klaster pada background 4

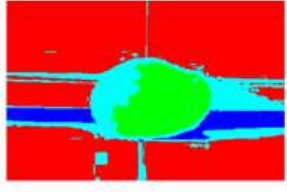

$\uparrow$

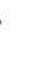

Gambar 10 Hasil Segmentasi 4 klaster pada background 5
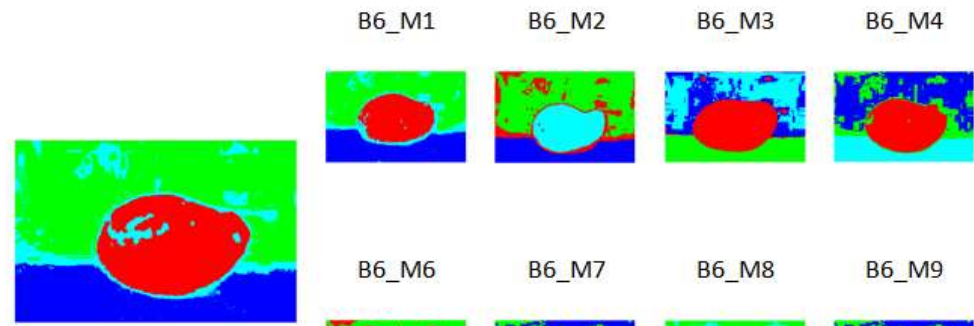

B6_M5

B6_M6

B6_M7

B6_M8

B6_M9

B6_M10
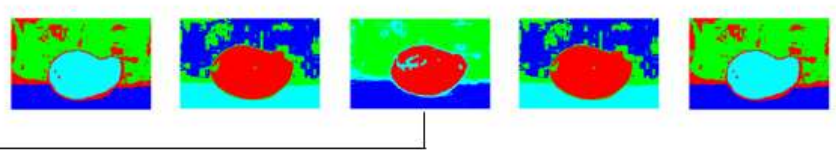

Gambar 11 Hasil Segmentasi 4 klaster pada background 6 


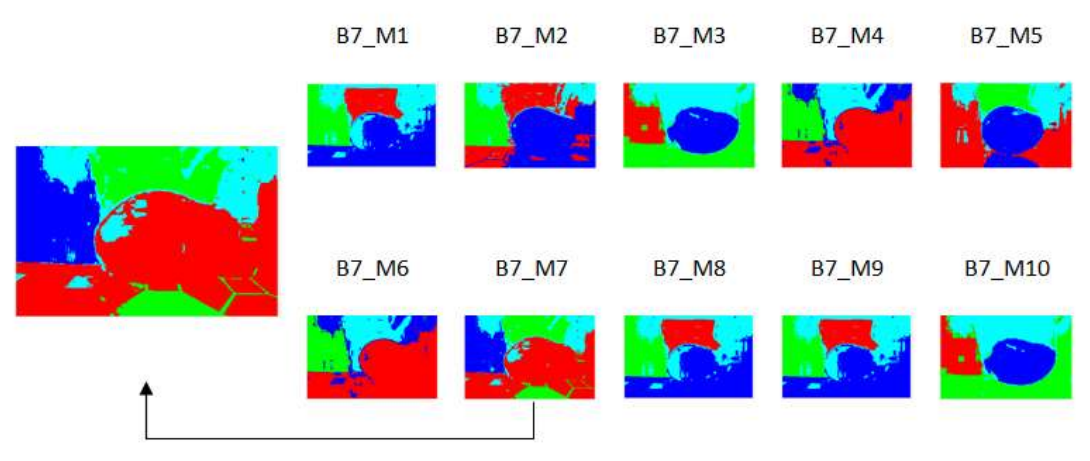

Gambar 12 Hasil Segmentasi 4 klaster pada background 7

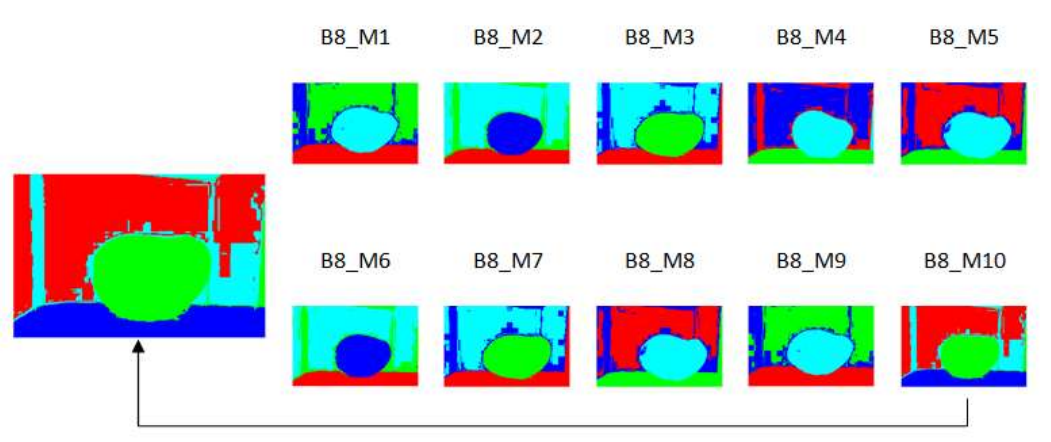

Gambar 13 Hasil Segmentasi 4 klaster pada background 8

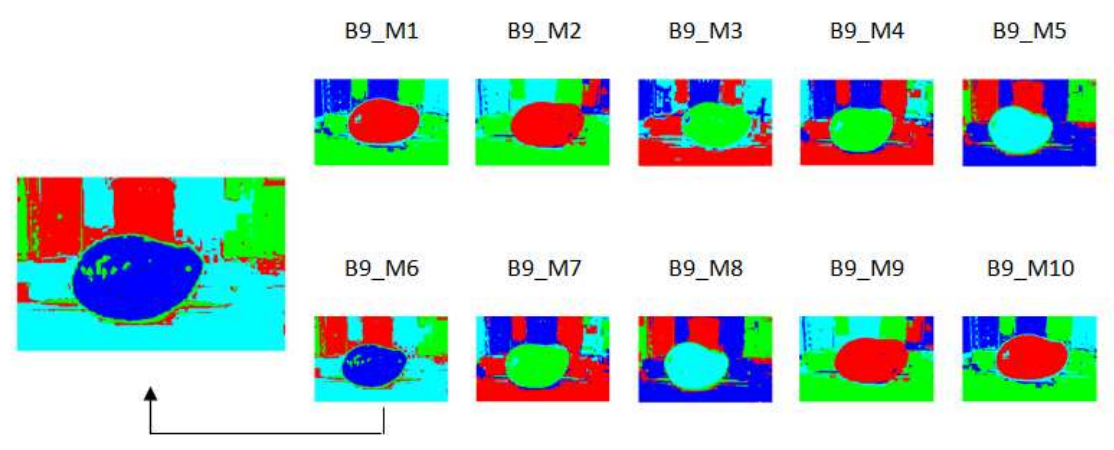

Gambar 14 Hasil Segmentasi 4 klaster pada background 9 


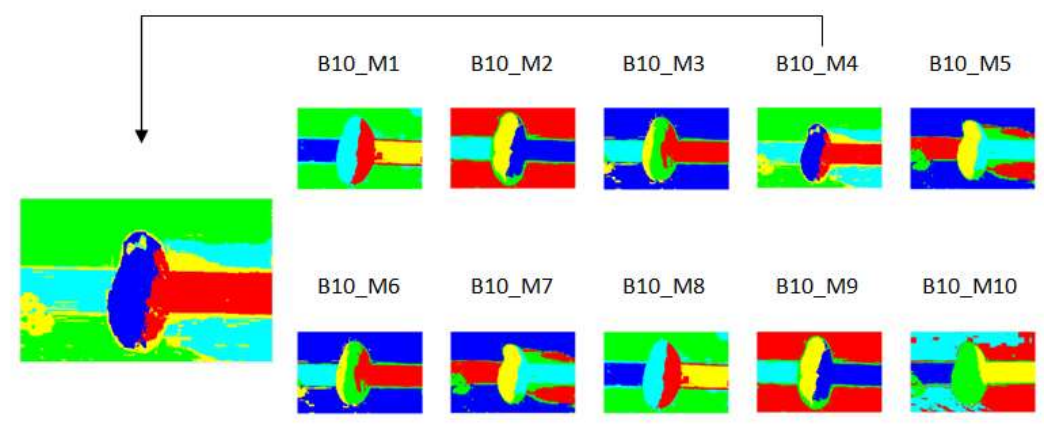

Gambar 15 Hasil Segmentasi 5 klaster pada background 10

Tabel 1 Hasil Pengujian MAE Seluruh Background

\begin{tabular}{|l|l|l|l|}
\hline & \multicolumn{3}{|c|}{ Nilai Rata-Rata } \\
\hline Background & 3 & 4 & 5 \\
& Cluster & Cluster & Cluster \\
\hline Background1 & $20,22 \%$ & $16,98 \%$ & $14,17 \%$ \\
\hline Background2 & $\mathbf{3 , 2 0 \%}$ & $\mathbf{3 , 4 1 \%}$ & $4,36 \%$ \\
\hline Background3 & $14,54 \%$ & $11,22 \%$ & $8,61 \%$ \\
\hline Background4 & $11,99 \%$ & $3,48 \%$ & $\mathbf{3 , 5 1 \%}$ \\
\hline Background5 & $8,89 \%$ & $5,76 \%$ & $4,94 \%$ \\
\hline Background6 & $9,21 \%$ & $4,15 \%$ & $5,23 \%$ \\
\hline Background7 & $20,32 \%$ & $15,96 \%$ & $5,84 \%$ \\
\hline Background8 & $14,96 \%$ & $4,13 \%$ & $5,12 \%$ \\
\hline Background9 & $7,45 \%$ & $4,08 \%$ & $4,96 \%$ \\
\hline Background10 & $19,93 \%$ & $11,46 \%$ & $9,55 \%$ \\
\hline Hasil & $\mathbf{1 3 , 0 7 \%}$ & $\mathbf{8 , 0 6 \%}$ & $\mathbf{6 , 6 3 \%}$ \\
\hline
\end{tabular}

Tabel 1 Hasil Pengujian Silhouette Coefficient Seluruh Background

\begin{tabular}{|l|l|l|l|}
\hline & \multicolumn{3}{|c|}{ Silhouette Coefficient } \\
\hline Background & 3 & 4 & 5 \\
& Cluster & Cluster & Cluster \\
\hline Background 1 & 0,27604 & 0,20161 & 0,14104 \\
\hline Background 2 & 0,3624 & 0,21218 & 0,2225 \\
\hline Background 3 & 0,15136 & 0,12376 & 0,15917 \\
\hline Background 4 & 0,35997 & 0,33509 & 0,32465 \\
\hline Background 5 & 0,58027 & $\mathbf{0 , 4 8 1 3 9}$ & $\mathbf{0 , 3 9 9 7}$ \\
\hline Background 6 & $\mathbf{0 , 5 8 6 0 3}$ & 0,41399 & 0,32372 \\
\hline
\end{tabular}

Pranata, et., al (Segmentasi Buah Mangga Menggunakan MLE dan GMM Sebagai Klasterisasi Pixel) 
Vol. 1, No. 1, Oktober 2020, Hal. $57-67$

\begin{tabular}{|l|l|l|l|}
\hline Background 7 & 0,23337 & 0,21163 & 0,25571 \\
\hline Background 8 & 0,47047 & 0,35279 & 0,33261 \\
\hline Background 9 & 0,37006 & 0,31089 & 0,27756 \\
\hline Background 10 & 0,37865 & 0,31435 & 0,17956 \\
\hline Hasil & $\mathbf{0 , 3 7 6 8 6}$ & $\mathbf{0 , 2 9 5 7 7}$ & $\mathbf{0 , 2 6 1 6 2}$ \\
\hline
\end{tabular}

Dapat dilihat dari Tabel 1 dan Tabel 2, bahwa dari citra mangga pada 3 cluster yang mendapatkan nilai Error paling kecil yaitu citra mangga pada background 2 sebesar 13,07\% dan citra magga yang mendapatkan nilai Silhoeutte Coefficient paling tinggi yaitu citra mangga pada background 6, pada 4 cluster yang mendapatkan nilai Error paling kecil yaitu citra mangga pada background 2 sebesar 8,06\% dan citra mangga yang mendapatkan nilai Silhoeutte Coefficient paling tinggi yaitu citra mangga pada background 5, dan pada 5 cluster yang mendapatkan nilai Error paling kecil yaitu citra mangga pada background 4 sebesar 6,63\% dan citra mangga yang mendapatkan nilai Silhoeutte Coefficient paling tinggi yaitu citra mangga pada background 5 .

\section{KESIMPULAN}

1. MLE mampu melakukan segmentasi mangga pada background yang berbeda dengan GMM sebagai klasterisasi pixel dengan rata-rata tingkat kesalahan (error) sebesar 13,07\% untuk 3 cluster, 8,06\% untuk 4 cluster, dan 6,63\% untuk 5 cluster. Hasil dapat dilihat di Tabel 4.21 pada subbab 4.2.

2. Performa MLE dan GMM untuk segmentasi mangga pada background yang berbeda dengan GMM sebagai klasterisasi pixel dengan rata-rata silhouette coefficient sebesar 0,37686 untuk 3 cluster, 0,29577 untuk 4 cluster, dan 0,26162 untuk 5 cluster. Hasil dapat dilihat di Tabel 4.22 pada subbab 4.2

3. Performa MLE dan GMM untuk segmentasi mangga pada background 6 mendapatkan nilai rata-rata silhouette coefficient tertinggi dibanding background lain untuk 3 cluster dan background 5 mendapatkan nilai rata-rata silhouette coefficient tertinggi dibanding background lain pada 4 cluster dan 5 cluster.

\section{SARAN}

1. Menggunakan Metode segmentasi yang lain.

2. Menguji data yang memiliki lebih dari satu objek pada citra.

\section{DAFTAR PUSTAKA}

[1] Alili, M. S., Bouguila, N., \& Ziou, D. ,2007, Online Video Foreground Segmentation Using General Gaussian Mixture Modeling, IEEE International Conference, Doi: $\underline{\text { 10.1109/ICSPC.2007.4728480 }}$

[2] Amaluddin, F., Muslim, M. A., \& Naba, A. , 2015, Segmentasi Kendaraan Menggunakan Gaussian Mixture Model (GMM) dan Fuzzy Cluster Means (FCM), 1 EECCIS Vol. 9, No. 1

[3] Aslam, N., \& Sharma, V. , 2017, Foreground Detection of Moving Object Using Gaussian Mixture Model. IEEE, Doi: 10.1109/ICCSP.2017.8286540 
Vol. 1, No. 1, Oktober 2020, Hal. $57-67$

[4]Bhatia, M., \& Gharge, S. , 2017, Segmentation of Brain MR Image using Fuzzy Local Gaussian Mixture Model, IEEE. Doi: 10.1109/EIC.2015.7230720

[5]Harrabi, R., \& Braiek, E. B. , 2014, Color Image Segmentation Using a Modified Fuzzy CMeans Technique and different color spaces: Application in the Breast Cancer Cells Images, IEEE, Doi: 10.1109/ATSIP.2014.6834612

[6]Hung, C., Nieto, J., Taylor, Z., Underwood. J., \& Sukkarieh. S. , 2013, Orchard Fruit Segmentation using Multi-spectral Feature Learning, IEEE. Doi: $\underline{10.1109 / \text { IROS.2013.6697125 }}$

[7]Kumase, M. R., Latumakulita, L., \& Nainggolan, N. , 2013, Segmentasi Citra Digital Ikan Menggunakan Metode Thresholding, Jurnal Ilmiah Sains Vol. 13 No. 1, Doi: https://doi.org/10.35799/jis.13.1.2013.2057

[8] Liu, J., Narayanan, D., Chang, K., Kim, L., Turkbey, E., Lu, L., Yao, J., \& Summers, R. M. 2015, Automated Segmentation Of The Thyroid Gland On Ct Using Multi-Atlas Label Fusion And Random Forest, IEEE, Doi: 10.1109/ISBI.2015.7164067

[9] Samet, R., Amrahov, S. E., \& Ziroglu, A. H. , 2012, Fuzzy Rule-Based Image Segmentation Technique for Rock Thin Section Images. IEEE. Doi: 10.1109/IPTA.2012.6469555

[10] Tran, K. A., Vo, N. Q., \& Lee, G. , 2013, Maximum Likelihood Estimation of Gaussian Mixture Models using PSO for Image Segmentation, IEEE. Doi: 10.1109/CSE.2013.81

[11] Zheng, Y., \& Zheng, P. , 2015, Hand Segmentation based on Improved Gaussian Mixture Model, IEEE, Doi : $10.1109 /$ CSA.2015.14

[12] Liu, W., Zhu, H., Wang, Y., Zhou, S., Bai, Y., \& Zhao, C. , 2013, Topology optimization of support structure of telescope skin based on bit-matrix representation NSGA-II, Chinese Journal of Aeronautics, 26(6), 1422-1429. https://doi.org/10.1016/j.cja.2013.07.046

[13] Mahiba, A. A., \& Durai, C. A. D. , 2012, Genetic algorithm with search bank strategies for university course timetabling problem, Procedia Engineering, 38, 253-263, https://doi.org/10.1016/j.proeng.2012.06.033

[14] Parera, S., Sukmana, H. T., \& Wardhani, L. K. , 2016, Application of genetic algorithm for class scheduling (case study: faculty of science and technology UIN Jakarta), 2016 4th International Conference on Cyber and IT Service Management, 1-5. https://doi.org/10.1109/CITSM.2016.7577525

[15] Yousef, A. H., Salama, C., Jad, M. Y., El-gafy, T., Matar, M., \& Habashi, S. S. , 2016, A GPU based genetic algorithm solution for the timetabling problem, 2016 11th International Conference on Computer Engineering \& Systems (ICCES), 103-109, https://doi.org/10.1109/ICCES.2016.7821982 